\title{
Effect of profitability of the Company in the Debt Policy
}

\section{(Case Studies on LQ45 Companies Listed on the IDX in 2016-2017)}

\author{
Rifda Fitrianti *, Ali Farhan **, Sri Rahayu **, Muhammad Andri Radiany **, Julikah ** \\ Sekolah Tinggi Ilmu Ekonomi Mahardhika, Surabaya, Indonesia
}

DOI: 10.29322/IJSRP.11.10.2021.p11808

http://dx.doi.org/10.29322/IJSRP.11.10.2021.p11808

\begin{abstract}
This study aims to examine the effect of profitability on corporate debt policy. The method used is quantitative with a sample of 22 companies listed on the IDX in the 2016-2017 period. The profitability variables tested were; ROE, ROA, and NPM with DER as the dependent variable. The test results show that Net Profit Margin and ROE have a significant positive effect on debt policy, while ROA has a significant effect on debt policy.
\end{abstract}

Index Terms- Profitability, Debt Policy, Agency Theory

\section{INTRODUCTION}

$\Gamma^{\mathrm{h}}$ he main objective of companies that have gone public is to maximize the welfare of shareholders. This goal becomes the basis for decision making in the company (Weston and Brigham, 1998). In running the company, shareholders delegate to other parties, namely managers, resulting in a separation between the ownership function and the management function. Decision making carried out by managers is often at odds with the main goals of shareholders. This conflict of interest arises because there is an agency conflict. Agency conflicts occur because managers have more information about the company's prospects than shareholders have, the information gap is called asymmetric information (Brigham and Houston, 2011). Agency conflicts generate agency costs, which will be reduced managerially if management is also part of a shareholder or bonus scheme, as compensation for costs of asymmetric information. To be able to align the interests of managers and shareholders that can be reduced by using debt as an alternative to bonus schemes or share ownership in order to control the manager's performance. According to Brigham and Houston (2011), one of the alternatives to reduce excess cash flow is a larger debt in the hope that debt service requirements will force managers to be more disciplined. Managers will be less likely to incur wasted expenses if the company has large debt service requirements.

In determining debt policy, there are several factors considered by companies in general, including profitability. Profitability is the company's ability to generate profits earned in a certain period. Companies with a very high level of profitability usually use relatively small amounts of debt. Because the high rate of return allows the company to do most of its funding through internally generated funds (Brigham and Houston, 2011). This is in accordance with the pecking order theory which establishes a sequence of funding decisions in which managers will first choose to use retained earnings, debt and share issuance as the last option (Mamduh, 2004). Profitability reflects earnings for investment funding. Myers (1984) suggests managers to use pecking orders for funding decisions. A pecking order is the order in which funds are used for investment, namely retained earnings as the first option, followed by debt and equity. The company's desire to borrow funds from outside will decrease if the retained earnings are owned by large companies, because the company will use retained earnings before deciding to use debt. This difference in thinking in making debt policy decisions is the basis for the research in this article, how a company behaves in a certain profitability towards its debt policy. Furthermore, this research will further discuss the effect of profitability on corporate debt policy, while profitability is proxied by the variables Return on Assets, Return on Equity, and Net Profit Margin.

\section{LITERATURE REVIEW}

Agency Theory

In every flow of economic information there is an issue regarding agency, this is explained further by Jensen (1983) that agency theory develops into two parts, namely positivist and principal-agent. Both have the same unit of analysis, namely the contract between the principal and the agent. It also has the same assumptions about people, organizations and information. However, they differ in mathematical rigor, dependent variable, and style. 
The theory of resistance tries to disentangle the most efficient contract to regulate principal - agent relationships on the basis of human behavior assumptions such as self-interest, limits of rationality, risk ad version, conflict within organizations, and information as a commodity that can be purchased (Alchian, and Demsetz, 1972). Next, this principal-agent contract will raise a question, which contract is more efficient for the company, is it a behavior-oriented contract such as salary or results-oriented contracts such as commission, stock options, transfer of property rights? As a result of the stimulus to the agent, this contract will give different results in terms of efficiency. This is because humans will have different rationalities and utilities when they achieve a goal. Agency structure can be implemented in many types of regulations, ranging from problems at the macro level, such as management policies, to the micro level such as human error, unprofessional management behavior. Agency theory can be implemented in the operations of an organization such as compensation, acquisition and diversification strategies, board of directors' relationships, ownership structures, financing, and innovation (Ang et al., 2000; Barnea et al., 1985; Bergen et al., 1992).

Researchers in the fields of accounting, economics, finance, marketing, political science, organizational behavior, and sociology have used agency theory in discussing social issues in organizations (Demski, and Feltham, 1978; Spence, and Zeckhauser, 1971; Fama, 1980; Basu et al., 1985; Mitnick, 1986; Eisenhard, 1985, 1988; White, 1985). When the contract between the principal and the indicator agent is the outcome, the agent will tend to behave in accordance with the principal's interests, and the information system can also prevent the agent from being opportunistic. Because effective information systems provide information for principals what agents are working on, as Fama (1980) and Fama and Jensen (1983) argue, explaining the effect of capital market information and efficient labor on managerial opportunism.

\section{Capital Structure}

\section{Trade Off Theory}

Myers (2001) revealed his opinion regarding the trade-off theory, that the company will decide to finance through debt to a certain level, where the tax savings (tax shields) from additional debt are equal to the cost of financial distress. The cost of financial distress is the cost of bankruptcy (bankruptcy costs) or reorganization, and agency costs that increase as a result of a decline in the credibility of a company. Trade-off theory in determining the optimal capital structure incorporates several factors, including taxes, agency costs and financial distress costs, but still maintains assumptions of market efficiency and asymmetric information as a balance and benefits of using debt. The optimal level of debt is achieved when the tax savings reach their maximum against the cost of financial hardship. Again according to Myers (1984) the pecking order theory states that "Companies with high levels of profitability have low levels of debt, because companies with high profitability have abundant internal sources of funds." In this theory there is no optimal capital structure.

\section{Financial Ratios}

To be able to help investors and creditors make business decisions, they compare the level of risk and returns that can be provided by the company, the comparison of the level of risk and the rate of profit sharing is commonly referred to as the financial ratio (White et al., 2002). To be able to compare the various levels of risk of return of the company, White et al (2002) divided it into the following categories, namely;

a) Solvency and long-term debt (leverage) analysis: assesses the Company's capital structure regarding long-term sources of funds and the Company's ability to settle its long-term obligations. In order to measure the Company's capital structure and its ability to settle its long-term obligations, the ratio:

\section{Debt to Equity Ratio}

Debt to Equity Ratio is a ratio that serves to assess each of its own capital used as debt collateral. This ratio is a ratio between the Company's entire debt to all equity. The greater this ratio, the more unfavorable it will be because the risk that may be borne by failure in the Company will be even greater. To calculate the Debt-to-Equity Ratio using the formula:

\section{Debt to Total Asset Ratio = Total Debt (Payable) $\times 100 \%$

$$
\text { Total Equity }
$$

b) Profitability analysis: measuring the level of company profit by comparing income and invested capital. To be able to analyze the level of profitability of the company can use ROE (Return on Equity) and NPM (Net Profit Margin). Return on Equity (ROE) is a ratio used to measure a company's ability to generate net income based on a certain share capital, this ratio is a measure of profitability from a shareholder's point of view. The higher the ROE number, the better the company's ability to generate profits from its own capital. To calculate the Return on Equity using the formula: 
Return on Equity = Net income

Total Equity

Meanwhile, NPM (Net Profit Margin) is a ratio that describes the Company's ability to generate net profit from the total sales it has made, the higher the NPM figure shows the level of efficiency of the Company in managing its operations. To calculate this ratio using the formula:

Net Profit Margin $=\underline{\text { Net Profit }}$

Total Sales

c) The profitability variable is measured using the Return on Asset Ratio (ROA). ROA analysis measures the company's ability to generate profits using the total assets (wealth) owned by the company after adjusting for the costs to finance these assets (Mamduh 2007).

Return on Equity $=$ Net income

Total Asset

\section{RESEARCH METHODOLOGY}

a) Framework of thinking

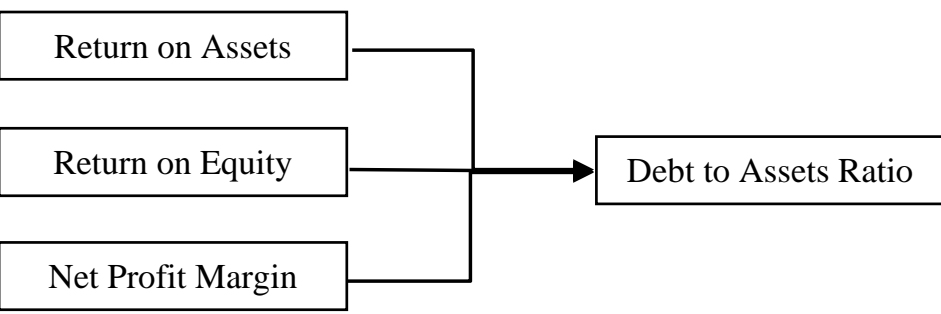

b) Type of Research

Sugiyono $(2004,2007)$ and Anshori and Iswati (2009) argue that research that aims to test the hypothesis on the relationship between two or more variables is called quantitative research. As a study that aims to examine the effect of ROA, ROE and NPM on DER, this research can certainly be categorized as a quantitative study. The variable used in this study is the dependent variable; Debt to Equity Ratio while the independent variables; Return on Assets Ratio, Return on Equity, and Net Profit Margin.

c) Population and Sample

In this study, the population used is the 2016-2017 annual report of all companies included in the Indonesia Stock Exchange. Meanwhile, the selected samples were companies listed in the LQ45 index on the Indonesia Stock Exchange in 2016-2017, the sample selection was carried out purposively with the aim of the selected samples in accordance with predetermined criteria. Purposive sampling is a method of determining the sample with certain considerations. The criteria that became the samples in this study were companies indexed in LQ45.

d) Type of Data

The data used is secondary data downloaded from the financial statements of companies listed on the IDX.

\section{DISCUSSION}

Normality test 
Normality test aims to test whether the regression model, or residual confounding variables have a normal distribution. To test whether the normal distribution of data or statistical test Kolmogorov-Smirnov Test. Residual normal distribution if it has a significance value $>$ 0.05 (Imam Ghozali, 2011). Based on Kolmogorov-Smirnov test results showed that the sig value 0,751>0,05. So, the data in this study means that it has been normally distributed.

\section{One-Sample Kolmogorov-Smirnov Test}

\begin{tabular}{|c|c|c|}
\hline & & $\begin{array}{l}\text { Unstandardiz } \\
\text { ed Residual }\end{array}$ \\
\hline N & & 24 \\
\hline \multirow[t]{2}{*}{ Normal Parameters ${ }^{2}$} & Mean & .0000000 \\
\hline & Std. Deviation & $9.92504468 \mathrm{E} 2$ \\
\hline \multirow[t]{3}{*}{ Most Extreme Differences } & Absolute & .138 \\
\hline & Positive & .092 \\
\hline & Negative & -.138 \\
\hline Kolmogorov-Smirnov $Z$ & & .676 \\
\hline Asymp. Sig. (2-tailed) & & .751 \\
\hline
\end{tabular}

a. Test distribution is Normal.

Table 1. Distribution Test

Multicollinearity Test

According to Imam Ghozali (2011) multicollinearity test aims to test whether the regression model found a correlation between independent variables (independent). To test multicollinearities by looking VIF each independent variable, if VIF <10, it can be concluded free data multicollinearities symptoms. From the test results in Figure 04 multicollinearities found that VIF $1,000<10$, meaning that the data in this study has been free of problems multicollinearity.

\section{One-Sample Kolmogorov-Smirnow Test}

\begin{tabular}{|ll|r|}
\hline & & $\begin{array}{c}\text { Unstandardiz } \\
\text { ed Residual }\end{array}$ \\
\hline Normal Parameters & & 24 \\
& Mean & .0000000 \\
Most Extreme Differences & Std. Deviation & $9.92504468 \mathrm{E} 2$ \\
& Absolute & .138 \\
& Positive & .092 \\
Kolmogorov-Smirnov $Z$ & Negative & -.138 \\
Asymp. Sig. (2-tailed) & & .676 \\
\hline
\end{tabular}

a. Test distribution is Normal.

Table 2. Multicollinearities Test

F Test

Based on the results of the $\mathrm{F}$ test, it shows that the sig. 0:00<0:05, thus meaning that simultaneous variable return on assets, net profit margin, and return on equity significantly influence the company's capital structure or policy of its debts, these findings are consistent with research Amelia and Sunarsi (2020) which states that the return on assets and return on equity simultaneously affects the debt-toequity ratio. 
ANOVA ${ }^{b}$

\begin{tabular}{|ll|c|r|r|r|r|}
\hline \multicolumn{1}{|c|}{} & \multicolumn{1}{c|}{$\begin{array}{c}\text { Sum of } \\
\text { Mquares }\end{array}$} & $\mathrm{df}$ & Mean Square & \multicolumn{1}{c|}{$\mathrm{F}$} & Sig. \\
\hline 1 & Regression & 1255482.034 & 3 & 418494.011 & 18.826 & $.000=$ \\
& Residual & 1756108.930 & 79 & 22229.227 & & \\
& Total & 3011590.964 & 82 & & & \\
\hline
\end{tabular}

a. Predictors: (Constant), ROA, Profit, ROE

b. Dependent Variable: DER

Table 3. Result of F Test

t Test

Coefficients ${ }^{\mathrm{s}}$

\begin{tabular}{|c|c|c|c|c|c|c|c|c|}
\hline \multirow{2}{*}{\multicolumn{2}{|c|}{ Model }} & \multicolumn{2}{|c|}{ Unstandardized Coefficients } & \multirow{2}{*}{$\begin{array}{c}\begin{array}{c}\text { Standardized } \\
\text { Coefficients }\end{array} \\
\text { Beta }\end{array}$} & \multirow[b]{2}{*}{$t$} & \multirow[b]{2}{*}{ Sig. } & \multicolumn{2}{|c|}{ Collinearity Statistics } \\
\hline & & $\mathrm{B}$ & Std. Error & & & & Tolerance & VIF \\
\hline \multirow[t]{4}{*}{1} & (Constant) & 163.758 & 28.938 & & 5.659 & .000 & & \\
\hline & Profit & 4.861 & 1.564 & .278 & 3.108 & .003 & .920 & 1.088 \\
\hline & ROE & 9.368 & 1.470 & 1.178 & 6.374 & .000 & .216 & 4.629 \\
\hline & ROA & -28.639 & 3.945 & -1.361 & -7.259 & .000 & .210 & 4.760 \\
\hline
\end{tabular}

a. Dependent Variable: DER

Table 4. Result of $\mathrm{t}$ Test

$\mathrm{Y}=163.758+4.861 \mathrm{X} 1+9.368 \mathrm{X} 2-28.639 \mathrm{X} 3+\mathrm{e}$

Where:

$\mathrm{Y}=$ Independent Variable (DER)

$\mathrm{X} 1=$ Net profit margin ratio

$\mathrm{X} 2=$ Return on Equity

X3 = Return on Asset

$\mathrm{e}=\mathrm{Un}$ researched variable

a) The Effect of Net Profit Margin on Debt-to-Equity Ratio

Based on the results of multiple regression analysis, it produces a Sig value of $0.03<0.05$, which means that the net profit margin has a significant effect on the debt-to-equity ratio, table B which shows a positive coefficient informs that the relationship between the debtto-equity ratio and the net profit margin has a positive effect, increasing the net profit margin. potential for the Company's tendency to increase its debt. This finding is different from some previous literacy, such as; Ismiyanti and Hanafi (2003), Myers and Majluf (1984), Sugiarto and Budhijono (2007), Seteven \& Lina (2011), Hardiningsih and Oktaviani (2012), Nabela (2012) and Yaniate and Niken (2012) who suggest that the level of Profits have a negative effect on the debt-to-equity ratio, because the availability of sufficient internal funds causes companies to tend to use their own capital rather than debt.

The debt-to-equity ratio shows the percentage of the Company's debt that is used for working capital, the greater the ratio, the greater the proportion of the Company's debt to its capital.

b) The Effect of Return on Equity on Debt-to-Equity Ratio

Based on the results of multiple regression analysis, the value of Sig is $0.00<0.05$, which means that ROE has a significant effect on the debt-to-equity ratio, table $\mathrm{B}$, which shows a positive coefficient, explains that the relationship between ROE and the debt-to-equity 
ratio has a positive effect, the higher the company's return on capital from profit. However, the greater the tendency for companies to support their capital with debt (an increase in the ratio of debt to equity). This finding is in line with the research results of Amelia and Sunarsi (2020) which state the same thing.

Return on Equity shows the ratio of net income to own capital, Return on Equity describes the Company's ability to generate profits provided to shareholders. ROE which continues to increase shows that the company can provide increased investment returns to shareholders

\section{c) Effect of Return on Equity on Debt-to-Equity Ratio}

In the results of multiple regression analysis to test the effect of Return on Assets on Debt to Equity Ratio, it produces a Sig value of $0.00>0.05$, which means that Return on Assets has a significant effect on the company's debt policy, table B shows a negative coefficient which means that the relationship between Return on Assets and debt to equity ratio has a negative effect, increasing Return on Assets will have the potential to reduce the tendency of companies to go into debt, this is in line with the results of previous research conducted by Sabir (2012), Fauzi (2013), Alzomaia (2014), and Umer (2014) which stated the same thing.

Return on Asset shows the ratio of net income to total assets of the company, Return on Asset describes the company's ability to generate assets from the turnover. ROA which continues to increase indicates that the Company has used its assets properly to generate profits.

\section{CONCLUSION}

Based on the results of multiple linear regressions on the variables Return on Assets, Return on Equity and Net Profit Margin on the Debt-to-Equity Ratio shows that; Net profit margin has a positive and significant effect on the level of the debt-to-equity ratio, this is related to the tradeoff theory in which management tends to seek third party funding in order to increase its profit through the efficiency of capital costs that are compensated for tax costs through interest on loans.

Return on Equity has a positive and significant effect on the debt-to-equity ratio. Return on assets, which is a proxy for company profitability, shows a significant negative effect on the debt-to-equity ratio, this is in line with Myers (1984) opinion that companies with good profitability tend to use their own capital rather than debt which tends to increase financial distress (Jensen)., 1976). The same opinion was also conveyed by Sabir (2012), Fauzi (2013), Alzomaia (2014), and Umer (2014).

\section{REFERENCES}

[1] Alzomaia, Turki S F. 2014. Capital Structure Determinants Of Publicly Listed Companies In Saudi Arabia. Scholarly Journals. 8, pp: 53-67.

[2] Amelia, R. W., \& Sunarsi, D. (2020). Pengaruh Return On Asset Dan Return On Equity Terhadap Debt To Equity Ratio Pada Pt. Kalbe Farma, Tbk.Ad-Deenar: Jurnal Ekonomi dan Bisnis Islam, 4(01), 105.

[3] Basu, A.,Lal, R.,Srinivasan, V., and Staelin, R. 1985.Sales-force compensation plans : An agency theoretic perspective. Marketing science. Vo.4. No.2 Pp.267-291.

[4] Bernard, S Black, Hasung Jang, Woochan Kim, Kyung Suh Park. 2003. Does Corporate Governance Affects Firm Value: Evidence From Korea, Social Science Research Network, Science Research Network electronic library at: http://ssrn.com/abstract=844744.

[5] Demski, J.,Feltham, G. 1978. Economic incentives in budgetary control systems. Accounting Review.Vol.53. No.2. Pp.336-359Eisenhardt, K. 1985. Control : Organizational and economic approaches. Management Science. Vol.31. No.1. Pp.134-149.

[6] Eisenhardt, K. 1988. Agency and institutional explanations of compensation in retail sales. Academy of management journal. Vol.88. No.3. Pp.288-307.

[7] Fauzi, Fitriya; Basyith, Abdul; Idris, Muhammad . 2013. The Determinants of Capital Structure: An Empirical Study of New Zealand-Listed Firms. Scholarly. Journals. 5.

[8] Fama, E.F. 1978. The Effect of a Firm's Investment and Financing Decision on the Welfare of its Security Holders. American Economic Review 68: June $272-284$.

[9] Ismiyanti, F. dan M. M. Hanafi. 2003. Kepemilikan Managerial, Kepemilikan Institusional, Risiko, Kebijakan Hutang, dan Kebijakan Deviden: Analisis Persamaan Simultan. Simposium Jurnal Akuntansi, Vol. 6, No. 7, hlm 260-277.

[10] Indahningrum, R. P. dan R. Handayani. 2009. Pengaruh Kepemilikan Manajerial, Kepemilikan Institusional, Dividen, Pertumbuhan Perusahaan, Free Cash Flow, Dan Profitabilitas Terhadap Kebijakan Hutang Perusahaan. Jurnal Bisnis dan Akuntansi, Vol. 11, No. 3, hlm.189-207.

[11] Jensen, M. C and Meckling, W.H. 1976. Theory of the Firm : Managerial Behavior, Agency Costs and Ownership Structure . Journal of Financial Economics, Oktober, 1976, V. 3, No. 4, pp. 305-360. Avalaible from: http://papers.ssrn.com.

[12] Myers S.,(1984).The Capital Structure Puzzle. Journal of Finance. 39;575-592.

[13] Mitnik, B. 1986. The theory of agency and organizational analysis. Unpublished working paper. University of Piyysburgh.

[14] Sugiyono, A. (2007). metode penelitian kuantitatif, kualitatif dan R\&D. Bandung: Alfabeta

[15] Steven. Lina. 2011. Faktor-Faktor Yang Mempengaruhi Kebijakan Hutang Perusahaan. Jurnal Bisnis Dan Akuntansi. Vol. 13, No. 3, Desember 2011, Hlm. 163 181.

This publication is licensed under Creative Commons Attribution CC BY.

http://dx.doi.org/10.29322/IJSRP.11.10.2021.p11808

WWW.ijsrp.org 


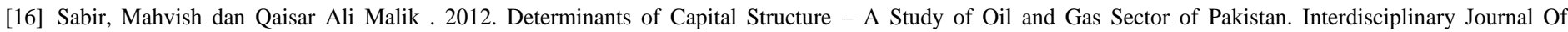
Contemporary Research In Business. 3 (10).

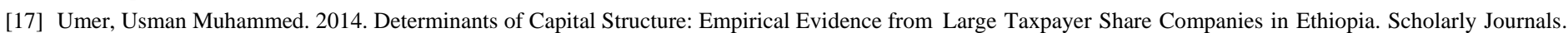
6, pp: 53-65.

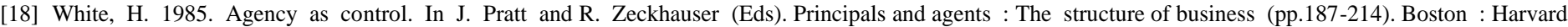
Business School Press.

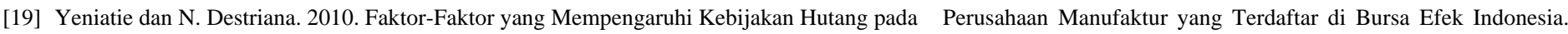
Jurnal Bisnis dan Akuntansi, Vol. 12, No. 1, hlm. 1-16.

\section{AUTHORS}

First Author - Rifda Fitrianti, Lecturer, rifda@stiemahardhika.ac.id

Second Author - Ali Farhan, Lecturer, alifarhanfarhan@yahoo.com

Third Author - Sri Rahayu, Lecturer, sri.rahayu@stiemahardhika.ac.id

Fourth Author - Muhammad Andri Radiany, Lecturer, muhammad.andri@stiemahardhika.ac.id

Fifth Author - Julikah, Lecturer, julika@stiemahardhika.ac.id

Correspondence Author - Rifda Fitrianti, rifda@stiemahardhika.ac.id 